\title{
Governance of the clean energy sector in Kazakhstan: impediments to investment
}

Anastasia Koulouri

Nikolai Mouraviev

This is the Accepted Manuscript, the final version of this paper was published in International Journal of Technology Intelligence and Planning

Koulouri, A. \& Mouraviev, N. 2018. Governance of the clean energy sector in Kazakhstan: impediments to investment. International Journal of Technology Intelligence and Planning.

DOI: 10.1504/IJTIP.2018.10015618 
This paper has been accepted for publication in the International Journal of Technology Intelligence and Planning, Inderscience (forthcoming in September 2018) $\mathbf{x} \mathbf{x} \mathbf{x} \mathbf{x} \mathbf{x}$

\title{
Governance of the clean energy sector in Kazakhstan: Impediments to investment
}

Anastasia Koulouri, Dundee Business School, Abertay University

and Nikolai Mouraviev, Dundee Business School, Abertay University

\begin{abstract}
This paper aims to identify the impediments to the development of the renewable energy sector in Kazakhstan through the lens of governance by drawing on the definition of governance as the execution of policy. The paper investigates the execution of the nation's policy on renewables by looking into the investment process, and provides an assessment of governance quality based on the interplay between state capacity and bureaucratic autonomy.

Critical impediments to investment in renewables include the multiplicity of provisions and agencies involved; the unstructured and ineffectual relations between renewable energy producers and operators; the ineffectual governance structures and mechanisms; the inconsistent development of the legal and regulatory framework; and the uncertainty regarding the resolution of legal disputes. Assessment of each of these indicates a very high degree of bureaucratic autonomy and limited state capacity, which, complemented by continuous dominance of the oil and gas sector, significantly impedes the government's attempts to expand the renewable energy sector. As reliance on oil and oil revenue continues, in the long term the nation's energy security is jeopardised. The paper contributes to knowledge by enhancing the understanding of governance of the renewables sector and providing insights into ways to facilitate investment.
\end{abstract}

Keywords: renewable energy, governance, bureaucratic autonomy, state capacity, Kazakhstan

\section{Introduction}

Kazakhstan is a resource-rich country both in traditional and renewable energy sources. However, much like other resource-rich countries, Kazakhstan is facing rapidly depleting reserves of fossil fuels, a natural resource of strategic importance for both its energy security 
and its sustainable economic development. Furthermore, despite its impressive economic growth since its independence from the Soviet Union in 1991, in recent years Kazakhstan experienced a series of economic downturns resulting from falling oil prices. It has therefore been increasingly interested in energy generation from renewable sources with the dual goal of future energy security and economic durability.

Kazakhstan's reliance on fossil fuels and oil in particular, due to their role as a principal source of energy and a critical source of budget revenue, has created path dependency, with the existing fossil fuel based energy sector impeding the development of renewables. Furthermore, the diversification of the nation's economy and its sustainability are compromised. The traditional energy sector is well established, it represents significant vested interests, and is supported by a strong lobby. Meanwhile the renewables sector is underdeveloped, with many elements (such as upstream and downstream supply chains, tariffs, qualified staff) yet to be established and institutionalised. Key institutions have competing visions on the nation's energy future (Asian Development Bank, 2010), and the two sectors -within the broader energy field- compete with, rather than collaborate and complement, each other. This is despite the nation's stated focus on renewable energy sources (RES) and significant efforts to promote the utilisation of renewables. The historically formed dominance of the traditional energy sector has led to the RES sector lagging behind, requiring systematic governmental support and focused efforts in the form of governance structures and mechanisms, macro-level projects, subsidies and incentives. If Kazakhstan is to be successful in addressing the entrenched distinction between the two sectors and achieving its goals of energy security and sustainable economic development, it is crucial that utilisation of renewables significantly expands.

This paper aims to investigate the impediments to the development of the RES sector from the governance perspective, focusing on the investment process in RES projects (henceforth the investment process). We explore the investment process as it emerges from the legal and regulatory provisions governing the RES sector. The legal and regulatory framework underpinning the investment process is a key element of the sector's governance and vital for its growth. Specifically, the research question is what are the critical impediments to the RES sector governance in the context of the investment process that hinder the development of the sector and the greater penetration of RES in the nation, in view of the government's stated commitment and significant efforts in that direction.

The paper's aim stems from the current condition of the RES sector in Kazakhstan. Over more than ten years ( since 2006), Kazakhstan has been undertaking actions attempting to develop policy, form the legal and regulatory framework, set up structures and institutions, 
organise financing, launch production facilities and develop energy generation from renewables. Whilst certain achievements have been made (to be discussed in a separate section below), progress has been limited and non-governmental investment is virtually non-existent. Moreover, certain governance elements appear to have been ineffectual and in some cases counter-productive, indicating a lack of forethought on their suitability and fitness-for-purpose. This explains the need to identify and assess impediments to investment in the RES sector, particularly in light of the sector's potential for development both in terms of the economic viability of renewable resource exploitation and of the existence of certain governance elements (such as regulatory bodies and industry associations). Whilst the dominance of the oil sector presents one set of barriers, it would be naïve and inadequate to associate all problems with the development of the RES sector merely with the nation's dependency on fossil fuels. Identifying the impediments to effective governance in the context of investment in the sector might therefore give valuable insights into how to enhance and accelerate investment in the sector and hence drive its expansion, which explains the significance of the study. Identification of impediments is the first step in understanding the future of the sector, which naturally should be followed by exploring ways to resolve governance problems. This however is beyond the scope of this paper.

The paper begins by outlining the approach and methodology adopted in this study. It then describes governance elements underpinning the investment process, and summarises key policy developments, outlines legal and regulatory provisions and details the investment process. The paper then critically reviews the stages of the investment process from the governance perspective, identifying impediments. It concludes by drawing insights into the implications of these impediments for potential investors, policy and governance of the RES sector and more broadly for Kazakhstan's energy security and sustainable economic development.

\section{Approach and methodology}

This paper draws on the theoretical insights into governance provided by Francis Fukuyama in his seminal text (Fukuyama, 2013). Governance is defined as 'a government's ability to make and enforce rules, and to deliver services regardless of whether that government is democratic or not' (Fukuyama 2013, p. 350). This paper adopts the view that governance focuses on execution (Fukuyama, 2013). Drawing on execution as the governance' core, the paper does not examine Kazakhstan's policy agenda for an increased utilisation of RES. Rather, it aims to 
identify impediments to the execution of the nation's policy on RES by looking into the investment process as underpinned by the legal and regulatory framework for the sector. The argument is that this process is one of the governance elements of the sector, with a very high significance for the sector's expansion.

Further, the paper draws on Fukuyama's proposed approach for evaluating the quality of governance. He proposed a framework focusing on the interaction between state capacity and bureaucratic autonomy (Fukuyama, 2013). For the purpose of this paper, we operationalise the definition of state capacity as the ability of the state to effectively implement goals in three areas: delivering services, managing the public sector, and influencing the economic and social behaviour of agents (individuals, firms, institutions). Bureaucratic autonomy refers to the degree of discretion that government officials possess. This degree is determined by the rules and regulations that guide (and/or frame) the work of bureaucrats. The foundation of these rules is accountability, the principles and boundaries of which are set by the government, although there might be a mismatch between the stated accountability (formal rules) and how it is managed in practice. In this paper, the adopted conceptual approach is useful as it serves well the research aim, i.e. permits to identify impediments to the implementation of Kazakhstan's RES policy and make their qualitative assessment through the prism of governance.

Data collection for this study was undertaken in Kazakhstan over 18 months in 201617. To capture the complexity of governance in the RES sector, 18 semi-structured interviews ranging from 30 to 90 minutes in duration were conducted. Interviewees -all Kazakhstani residents- were selected using purposive and snowball sampling (Heckathorn, 1997) and included: (a) government experts working in the RES sector; (b) senior managers of private RES companies; and (c) academics (at various levels). The principal criterion for selecting an interviewee was whether a person possesses an expert level of knowledge of the conditions and challenges in the sector. Although the sample size was small, the study reached data saturation, confirmed by the final round of interviews, with additional interviews providing almost no new data, and comments and opinions highly similar to those from interviews conducted earlier. Interview data were complemented by content analysis of policy documents, laws, government statements and other written materials that capture the development of Kazakhstan's RES sector (Bernard and Ryan, 2010).

Data analysis was driven by the emanating data themes and the chosen approach. The frequently noted and dominant themes -and the secondary topics or sub-themes in eachemerging from the raw interview data were identified and shaped by the adopted governance perspective (Saldana, 2009; Guest et al, 2012). The items in each theme and sub-theme were 
prioritised based on the interviewees' opinions (Saldana, 2009). This allowed capturing common patterns, shared concerns and trends related to governance in the RES sector (Thomas, 2006). Thematic analysis of qualitative data was most appropriate for this study as it permitted the well-structured and systematic, owing to the adopted approach, treatment of data, and successfully served the study's aim to identify barriers to the effective governance of the RES sector with particular focus on the investment process (Bernard and Ryan, 2010).

\section{Governance elements of the RES sector: Kazakhstan's progress to date}

This section provides an account of the steps Kazakhstan has been making in establishing and strengthening the RES sector, which is necessary for an assessment of governance and specifically impediments to investment in the next section. It begins by highlighting Kazakhstan's dependency on fossil fuels despite its wealth in renewable natural resources. It then discusses the evolution of the country's policy direction and agenda for the sector and the development of the legal and regulatory framework for RES. Finally, it outlines the process an investor has to follow for launching a RES energy-generating plant, from conception to commissioning.

\subsection{Energy profile}

Kazakhstan is a resource-rich country in terms of non-renewable (oil, gas, coal, uranium) and renewable (wind, solar, biomass, hydro, geothermal) energy sources and ranks amongst the largest energy producers in Central Asia (International Energy Agency, 2015). The country's potential for utilising RES is significant, estimated at over 1 trillion $\mathrm{kWh} / \mathrm{year}$, with power generation from wind and solar resources considered both technically and economically viable (Energy Chapter Secretariat, 2013; REEEP, 2014). Nonetheless, as Table 1 shows, the country's energy generation is dominated by fossil fuels.

Table 1. Power generation in Kazakhstan by source (\%)

\begin{tabular}{|c|c|c|}
\hline & 2015 & 2016 \\
\hline Fossil fuels & 81.6 & 79.4 \\
\hline Hydro & 10.2 & 12.3 \\
\hline Gas turbine & 8.0 & 7.9 \\
\hline
\end{tabular}




\begin{tabular}{|c|c|c|}
\hline Solar and wind & 0.2 & 0.4 \\
\hline Total & 100 & 100 \\
\hline
\end{tabular}

Source: Kazakhstan Electricity Grid Operating Company (KEGOC), 2017.

\subsection{Legal and regulatory framework}

Recognising the need to limit its reliance on exhaustible resources and reduce its fiscal vulnerability to oil market fluctuations, since 2006 Kazakhstan has been making efforts to transition to a more sustainable economic model. Key policy instruments aiming to achieve steady economic growth and ensure energy security by developing the RES sector include: the Sustainable Development Concept (Decree of the President of the Republic of Kazakhstan (RK) on the Concept of transition of the RK to sustainable development, 2006); the Kazakhstan 2050 Strategy (Kazakhstan 2050, 2012); and the 'Green Economy' Concept (Decree of the President of the RK on the Concept of transition of the RK to 'green economy', 2013).

Alongside with outlining a policy framework, Kazakhstan has been developing a legal framework to support its policy actions for growing and strengthening the RES sector. A host of legislative ${ }^{1}$ and regulatory provisions ${ }^{2}$ govern the power sector including RES. In addition, the Law of the RK on Support of the Use of Renewable Energy Sources, henceforth the Law on RES (2009; adopted in 2009, amended in 2013), provides the foundations for the legal framework and support mechanisms for increasing the utilisation of RES through a number of stipulations including:

- Regional authorities are charged with the responsibility to allocate land plots for the construction of facilities using RES (amendment of Article 90 of the Land Code, 2003);

- Regional power grid/transmission companies are charged with the responsibility and have the obligation of connecting RES energy-generating facilities to the grid;

- Electricity generated from RES is to be bought at fixed feed-in-tariffs (FiT) that entered into force in June 2014 and are guaranteed by the government for 15 years; 
- Producers of renewable energy are exempt from payments for power transmission services (although this might change should the Law on Land Economy be introduced (International Finance Corporation, 2015));

- KEGOC (Kazakhstan Electricity Grid Operating Company) was assigned the task of establishing the Financial Settlement Centre for Support to Renewable Energy Sources LLP (FSC) to be responsible for the centralised purchase and sale of all electricity produced by RES facilities and supplied to electric networks in Kazakhstan's Unified Power System ${ }^{3}$ (traditional resource energy producers);

- Traditional resource energy producers are obliged to purchase all the energy generated by RES facilities, via the FSC. This means that traditional energy producers have been assigned the role of an intermediary between RES producers and end-users.

These provisions were further strengthened by the Law of the RK on Amendments and Addenda to Some Legislative Acts of the RK on the transition of the RK to a 'green economy' (2016), which came into effect on 1 July 2016. Its provisions regarding the electric power industry include:

- Adoption of the annual indexation of the feed-in-tariffs for electricity generated from RES to reflect exchange rate fluctuations between the national currency and major foreign currencies.

- Consideration, when determining maximum consumer tariffs, of the cost of electricity produced by RES energy producers and purchased from the FSC by traditional resource energy producers.

- Endowment of the FSC with a reserve fund to be used to cover its cash deficits and debts to RES energy producers stemming from non- or delayed payment for electricity supplied by them -through FSC- to traditional resource energy producers.

\subsection{The investment process}

The Kazakhstani government has taken specific steps to underpin the implementation of its policy on RES. It has been working with international organisations (e.g. UNDP) and international financing institutions (e.g. the European Bank for Reconstruction and Development (EBRD)) to align its policy instruments with international standards, develop the 
legal and regulatory framework governing the RES sector and reduce corruption. In addition, even before the adoption of the Law on RES (2009), there has been a host of implementation initiatives including state programmes, action plans, collaborative projects with international institutions and "raising awareness" activities.

In 2015, the International Finance Corporation, in partnership with Kazakhstan's Ministry of Energy and the Clean Technology Fund, published a guide for investors interested in undertaking a RES project in the country (International Finance Corporation, 2015). The guide outlines the investment process which has multiple, inter-linked stages -necessitating the involvement of numerous agencies- for the design, approval, construction and commissioning of energy producing plants from RES. An investor wishing to develop such a facility has to:

1. Legalise the rights to a plot of land for the specific purpose;

2. In the case of a hydro installation, obtain a water use permit;

3. Arrange for the proposed facility's connection to the grid through KEGOC or one of the regional network companies;

4. Conduct a feasibility study, followed by preparation of the design documentation and cost estimates;

5. Apply for the inclusion of the proposed facility in the list of energy generation companies using RES (held by the Ministry of Energy);

6. Sign a Power Purchasing Agreement with the FSC;

7. Construct the facility and connect it to the grid;

8. Receive the Certificate of Acceptance following checks of conformity to construction regulations and the original design; and

9. Commission the facility after online testing of the power plant.

Figure 1 summarises the stages of the process, from project inception to plant commissioning, providing details of sub-stages, the number of government agencies involved and the estimated time required for completion.

Figure 1. The investment process in RES projects 


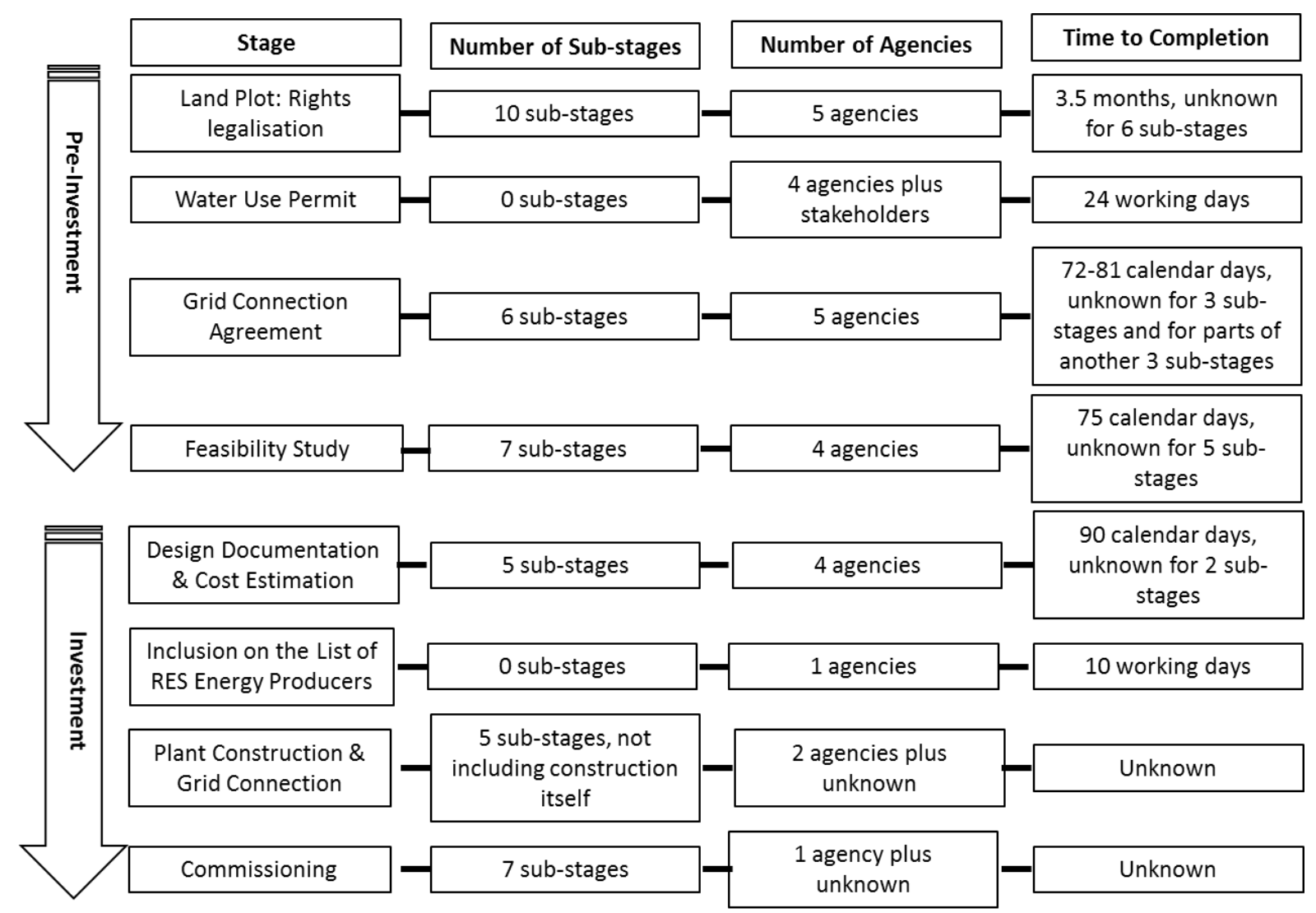

Source: Compiled by the authors.

The investment process is dictated and governed by the legal and regulatory framework pertaining to the RES sector. However, despite the government's stated aim to facilitate investment in it, this process presents a number of challenges for an investor.

In the past 10 years, the Kazakhstani government has developed numerous policies providing direction, setting targets and undertaking specific initiatives in its quest to dissever its energy security and sustainable economic development from fossil fuels. It has further made significant progress in establishing the necessary regulatory and legal framework to underpin the development of renewables. These efforts however have yet to show results: the RES sector is still in its infancy in comparison to the long- and well- established oil and gas sectors. This state of affairs suggests the existence of impediments to achieving the government's aims. In an attempt to identify those barriers relating to the governance of the RES sector in Kazakhstan and in particular, to the governance of investment activities in it, the following section provides a critical analysis of the investment process. This will permit to assess relevant laws and regulations, the institutional context, and the supporting initiatives and mechanisms through the lens of governance. 


\section{Critical review of the investment process in RES projects in Kazakhstan}

Key elements of the investment process follow from the Law on RES (2009), which includes a number of provisions aiming at supporting the development of the RES sector. However, when critically reviewed, certain provisions emerge as impediments to investment in it and consequently to its expansion and the growth of the Kazakhstani economy. These impediments are:

- Multiplicity of provisions and agencies;

- Unstructured and ineffectual relations between RES producers and operators;

- Ineffectual governance structures and mechanisms;

- Inconsistent development of the legal and regulatory framework; and

- Uncertainty regarding legal disputes.

This section discusses these impediments through the lens of governance, i.e. an ability to deliver policy objectives.

\subsection{Multiplicity of provisions and agencies}

As Figure 1 shows, the investment process is complex involving multiple stages and requiring interaction with and input from numerous agencies at the local, regional and national levels. Underlying this process is a multiplicity of legal and regulatory provisions that an investor needs to adhere to and successfully navigate at each stage in order to progress to the next. The sheer number of stages and sub-stages, agencies and laws and regulations renders the process cumbersome and lengthy. Moreover, the existence of multiple laws and regulatory requirements, rather than a single coherent framework, presents a fragmentation of the legal and regulatory framework. This means an increased potential for overlap and duplication of the requirements to be satisfied and laws to adhere to by the investor, and of the effort required by both investors and agencies.

In addition, the involvement of numerous institutions/agencies in administering the process and enforcing laws and regulations presents several inherent challenges: (1) unnecessarily complicated procedures; (2) lack of clarity and transparency; (3) dependence on inter- and intra- agency relations; and (4) obscure lines of communication. For example, at stage 1 of the process (legalisation of rights to a land plot), the investor is required to file an 
application for the rights to a plot with the Local Executive Body. Two separate departments the Land Relations Department and the Department of Architecture and Municipal Planningreview it. Its approval requires the agreement of both. There is no information/clarity on: (1) which of the two Departments involved is the lead one; (2) whether and/or how the two Departments carrying out the review are in communication during the review process; (3) how they reach consensus and what happens if they disagree in their assessment of the application; (4) what is the investor's line of recourse should the application be rejected by one or both Departments or (5) whether the investor would be informed of why, and by which Department, if the application was rejected.

As one interviewee pointed out: 'The regulatory framework makes difficult to attract investment...there are people with money but they are reluctant to invest as the rules are complicated...A big problem for foreign investors is knowing the system and the mentality'.

In terms of time required from inception to commissioning, the completion of each stage requires significant (if at all known) time which in practice, for some stages, our interviewees confirmed is significantly longer than stated. Interviewees suggested that this is due to an attempt by these agencies to show 'thorough examination of the documentation' and hence demonstrate quality assurance and employ anti-corruption procedures. According to the experience of one interviewee: 'When we applied for the approval of the Feasibility Study (stage 4 of the investment process) instead of 45 calendar days (as per stated timescale) the approval took 6 months. The agency requested the same details 4 times...Agencies hold on to the paperwork to show that they followed procedure and do a thorough review as it is fashionable to show that they are fighting corruption'.

However, in reality, this is a significant disincentive for potential investors and it compares poorly with investment processes of other emerging and transitional markets with RES potential (International Finance Corporation, 2015), making entering the Kazakhstani energy market far less attractive for potential investors.

Finally, successfully navigating through each stage and preparing the required documentation necessitates the services of licenced specialists and expert consultants. This means that significant expenditure and time resource commitment are required before the approval of the project, at the "pre-investment" stages (see Figure 1). Furthermore, our interviewees stated that some of the specialist companies do not actually have the required expertise and, hence, in their words, 'the quality of documents provided (to investors) is substandard'. 
To summarise, investors' engagement with the multiplicity of legal and regulatory provisions and numerous agencies, with a requirement to commit to large upfront costs and significant time expense, forms the first set of impediments to investment in the RES sector.

\subsection{Unstructured and ineffectual relations between RES producers and operators}

Under the Law on RES (2009), RES facilities should be connected to the grid, whilst transmission of electricity from renewable sources should be free for producers of clean energy. However, the Law on RES fails to give clear guidance on the potential liability of electrical network operators and the system operator in case of their refusal or delay to (1) provide Technical Specifications to RES investors and/or (2) conclude the agreement for transmission services (Power Delivery Scheme) with them (Stage 3 of the investment process). In practice, the requirement of free network development and transmission services may lead to network operators being reluctant to provide their services to RES investors, or to lacking interest to conclude service agreements with them with no clear line of recourse open to investors. This is because both the development of the necessary connecting infrastructure and the transmission of power incurs an additional cost for network companies and the system operator.

Moreover, there is no network connection agreement as such between the RES investor and the electrical network operator, making the Technical Specifications a "de facto contract" (International Finance Corporation, 2015). In this context, electricity producers can receive network access only by signing a contract for technical dispatch with the system operator, using a contract template that does not account for the nature of RES (International Finance Corporation, 2015).

Essentially, RES investors are left to their own devices, whilst government support in the form of a clear, transparent and easy to follow procedure for becoming connected to the grid is missing. In addition, the incentives for network companies to provide the necessary infrastructure and for the system operator to transmit renewable energy are also missing. The situation RES investors find themselves in is further compounded by the lack of proper regulation of the relations between RES producers, network companies and the system operator: a network company can refuse to connect a RES facility or the system operator can refuse to transmit RES generated electricity without penalty. 


\subsection{Ineffectual governance structures and mechanisms}

The Kazakhstani government established the FSC as the sole buyer of electricity generated from RES. However, since its inception, its creditworthiness has been a concern for lenders and investors. As one interviewee highlighted: 'International financial institutions, such as the International Finance Corporation, are scared to finance RES projects as the lack of a reserve fund means that if something goes wrong they have nothing to fall back to'.

The FSC has relatively recently (July 2016) been endowed with a reserve fund; much later than its creation following the Law on RES in 2009. This meant that as a limited liability company, the FSC was not required by law to have a capital greater than USD 600, which could not cover its liabilities. The endowment of the reserve fund in 2016 is a positive step, but it is yet to be proven whether the measure will alleviate lenders' and investors' reservations regarding the FSC's creditworthiness.

This is of critical significance given the limitations that traditional energy producers face when they consider raising end-user tariffs to cover the cost of buying, from the FSC, electricity generated from RES. This might in turn lead to delays or non-payments to the FSC, which consequently might be unable to meet its obligations to renewable energy producers and potentially lead to its insolvency. Should this happen, clean energy producers will be left with debts that they cannot recoup and no buyer for the electricity they generate.

A key governance mechanism put in place to regulate the RES sector is the list of eligible RES energy producers that Kazakhstan's Ministry of Energy compiles. RES investors prior to starting plant construction are required to register on this list. However, there is no clearly established procedure and timeframe for an investor applying for inclusion in it. In addition, the law does not provide the criteria for assessing investors' applications; in other words, it is left to the discretion of the Ministry of Energy officials, thus lacking transparency. Anecdotal evidence indicates that the Ministry of Energy in practice applies an unofficial annual deadline for applications (15 November of each year) for inclusion in the list for the following year. The Investor Guide by the International Finance Cooperation (2015) states that the timescale for assessing and deciding on an application for inclusion in the list is 10 business days (International Finance Cooperation 2015, p. 14). In this study, the interviewees reported that, in their view, the number of RES energy producers to be included in the list has an unofficial annual cap. Interviewees further stated that certain organisations on the list do not have the necessary credentials and experience in the sector and that their inclusion was the outcome of a bureaucratic exercise rather than proper assessment. This means that a mechanism 
designed to ensure the effective regulation of the RES sector is non-transparent, inept and counter-productive enabling the use of arbitrary judgement and hence fostering partiality and corrupt practices. Nonetheless, one interviewee pointed out that: 'The list is necessary; otherwise there would be more bogus, unfeasible, substandard projects'.

\subsection{Inconsistent development of the legal and regulatory framework}

Although certain supporting mechanisms for the RES sector have been legislated for, their implementation through developing the necessary regulatory elements often has been significantly delayed. As one of our interviewees stated: 'The government starts with pilot pet- projects and then thinks about regulation'. For example, feed-in-tariffs for electricity produced from RES were enshrined in law in 2009. However, it was not until 2015 when the Ministry of Energy approved the associated regulation (Point 9 of the Rules for Determining the Tariff for the Support of Renewable Energy Sources approved by the Order of the Minister of Energy of the Republic of Kazakhstan No. 118, dated 20 February 2015). Likewise, the indexation of feed-in-tariffs for currency fluctuations has relatively recently been embedded in legislation (July 2016). Nonetheless, it is unclear whether the relevant mechanisms have been put in place in a timely fashion: one of our interviewees emphasised that the indexed tariffs were introduced as late as April 2017. This means that RES investors face an uncertain legal and regulatory environment and certain stages of the investment process are not supported by the necessary mechanisms.

\subsection{Uncertainty regarding the resolution of legal disputes}

Despite the rapid development of Kazakhstan's legislative framework, it still does not embed some key legal concepts that need to be integrated in, for example, international corporate law (Law Gazette, 2013). Kazakhstan does not have bilateral treaties allowing judgements from Western European or North American courts to be enforceable in Kazakhstan. Similarly, Kazakhstan is not party to multilateral international treaties on enforcing foreign court judgements in the country. This creates a significant risk for foreign investors. Those who opt for contracts in which -despite the lack of enforceability- the governing law is not the Kazakhstani one, in case of a dispute face the non-enforceability of judgements. Those who opt for a contract using the Kazakhstani law as the governing law, face a number of challenges that might impact on a potential resolution. These challenges include the lack of clarity of the 
Kazakhstani law; the limitations on the amount of damages and legal costs that can be awarded by a Kazakhstani court; the lack of experience of local judges in dealing with certain types of cases; and lower international recognition that Kazakhstani judgements carry as opposed to, for example, judgements from the UK courts. The country is now party to: the New York Convention on the Recognition and Enforcement of Foreign Arbitral Awards (1958); the European Convention on International Commercial Arbitration (1961); and the Convention on the Settlement of Investment Disputes between States and Nationals of Other States (1965). Furthermore, Kazakhstan has a system of arbitration courts outwith the system of state courts. According to this system, if the parties in dispute have an arbitration agreement and one of them is not a resident of Kazakhstan, the dispute can be referred to the arbitration courts for resolution. However, not all cases can be referred to arbitration (e.g. disputes involving immovable property in Kazakhstan) and an arbitration award has to be enforced by a Kazakhstani state court, which might not be happening in practice. This means that investors and particularly foreign investors face uncertainty -and hence significant risk- when it comes to the enforceability of arbitration awards and of judgements on contracts governed by other than the Kazakhstani law.

\section{Discussion: Assessing the governance of the RES sector}

The critical review of the investment process has identified five impediments relating to: the number of provisions and agencies involved; the relations between RES producers, network companies and the system operator; the existing governance structures and mechanisms; the development of the legal and regulatory framework; and the resolution of legal disputes.

Considering each of these impediments, there is a noted lack of rules and regulations to guide and/or frame the work that bureaucrats - involved at each stage of the investment process - have to perform. This signifies extreme bureaucratic discretion, the existence of which may be linked to corruption (Meón and Sekkat, 2005). This finding is aligned with those in existing literature. With little or no accountability, a high degree of discretion may result in partiality, favouritism and corrupt practices (Klitgaard, 1988; Fukuyama, 2013) hindering investment (Meón and Sekkat, 2005). In contrast, strong accountability, free from partiality and corruption, is likely to encourage innovative behaviour of government staff (Fukuyama, 2013).

A key feature of the Kazakhstani state is a high degree of political and fiscal centralisation, with the latter supporting the former (Bhuiyan and Amagoh, 2011). The investment process reflects this. It starts at the local level when an investor applies for the rights 
to a land plot (stage 1 of the investment process) and it then moves on to the national level when an investor applies for inclusion in the list of approved RES producers (stage 6 of the investment process). In practice, this high degree of power centralisation means that, at the regional and local levels, bureaucrats have limited autonomy for strategic decisions (needing to consult with central government) and greater discretion for operational decisions (when the primary goal is to satisfy the principal, in the context of the principal-agent theory). As a consequence, accountability of bureaucrats at the regional and local levels is severely limited if at all in existence. The noted lack of rules and regulations in relation to the investment process exacerbates the already existing limited accountability.

Moreover, all impediments point to the existence of numerous ineffective structures and processes, indicating that the government paid insufficient attention to the potential implications of governance elements whilst designing them in order to translate policy into action. The existence of ineffectual structures and processes inhibits the ability of the state to deliver clean energy to the public, manage public services efficiently, and influence the economic and social behaviours of investors and firms interested in the RES sector, and the institutions involved in its governance. These inefficiencies and impediments curtail the capacity of the state to deliver on its stated goals relating to the sector.

Applying Fukuyama's framework to the assessment of the quality of governance (Fukuyama, 2013), we conclude that the existing extreme bureaucratic autonomy and exhibited limited state capacity have had a negative impact on the Kazakhstani government's efforts to achieve its policy objective, that is the expansion of the RES sector and the increase of the utilisation of renewable energy. This negative impact in delivering the desired outcome demonstrates the diminished efficacy of the governance of the RES sector with numerous implications for investors, lenders, the government and the nation to be discussed in the following section.

\section{Conclusion}

Table 2 summarises the impediments to the RES sector expansion. It further outlines the main points drawn from their assessment through the lens of effective governance and the implications that follow for investors, lenders, the government and the nation.

Table 2. Summary of impediments: assessment through the lens of effective governance 


\begin{tabular}{|c|c|c|c|}
\hline Impediments & Core issues & $\begin{array}{c}\text { Comments } \\
\text { (these apply to each } \\
\text { impediment) }\end{array}$ & $\begin{array}{c}\text { Implications } \\
\text { (these result from all } \\
\text { impediments) }\end{array}$ \\
\hline $\begin{array}{l}\text { Multiplicity } \\
\text { of provisions } \\
\text { and agencies }\end{array}$ & $\begin{array}{l}\text { - Lengthy and cumbersome } \\
\text { process and procedures. } \\
\text { - Overlapping/duplicated } \\
\text { requirements. } \\
\text { - Overlapping and/or unclear } \\
\text { responsibilities of agencies. } \\
\text { - Lack of transparency and } \\
\text { clarity. } \\
\text { - Upfront costs for investors. }\end{array}$ & \multirow{5}{*}{$\begin{array}{l}\text { - Lack of rules and } \\
\text { regulations framing and } \\
\text { guiding bureaucrats' } \\
\text { work signifies extreme } \\
\text { bureaucratic discretion, } \\
\text { which together with lack } \\
\text { of accountability may } \\
\text { result in partiality, } \\
\text { favouritism and corrupt } \\
\text { practices. } \\
\text { Ineffective structures } \\
\text { and processes limit the } \\
\text { state's ability to } \\
\text { influence the economic } \\
\text { and social behaviour of } \\
\text { individuals, firms and } \\
\text { institutions in relation to } \\
\text { RES. As such, they limit } \\
\text { the state's capacity to } \\
\text { deliver the desired } \\
\text { outcome. } \\
\text { - Overall, extreme } \\
\text { bureaucratic autonomy } \\
\text { and limited state } \\
\text { capacity have led to } \\
\text { failure in achieving the } \\
\text { stated objective, which } \\
\text { is to increase the } \\
\text { utilisation of RES. } \\
\text { ineffective governance } \\
\text { of the RES sector. }\end{array}$} & \multirow{5}{*}{$\begin{array}{l}\text { For investors: } \\
\text { - Disincentivisation. } \\
\text { For lenders: } \\
\text { - Reluctance to finance } \\
\text { RES projects. } \\
\text { For government: } \\
\text { - Current governance } \\
\text { structures and } \\
\text { processes need to be } \\
\text { revised. } \\
\text { - The assessment of } \\
\text { implications of } \\
\text { governance elements } \\
\text { should be incorporated } \\
\text { in decisions regarding } \\
\text { the design of } \\
\text { governance structures } \\
\text { and processes prior to } \\
\text { implementation. } \\
\text { - Particular attention } \\
\text { needs to be paid to } \\
\text { incentive measures for } \\
\text { investors, network } \\
\text { companies and the } \\
\text { system operator. } \\
\text { For the nation: } \\
\text { - In the long term, } \\
\text { energy security is } \\
\text { jeopardised. } \\
\text { economic development } \\
\text { model is hindered. } \\
\text { the diversification of } \\
\text { the economy (related to } \\
\text { the energy sector) is } \\
\text { impeded. } \\
\text { revenues continues. } \\
\text { bonsequently, the } \\
\text { vulnerable to oil price } \\
\text { fluations. } \\
\text { - } \\
\text { - } \\
\text { - }\end{array}$} \\
\hline $\begin{array}{l}\text { Unstructured } \\
\text { and } \\
\text { ineffectual } \\
\text { relations } \\
\text { between RES } \\
\text { producers and } \\
\text { operators }\end{array}$ & $\begin{array}{l}\text { - Lack of incentives for network } \\
\text { companies and the system } \\
\text { operator to connect RES } \\
\text { producers to the grid and } \\
\text { transmit the energy they } \\
\text { produce. } \\
\text { - Additional costs (for network } \\
\text { companies and system operator) } \\
\text { to build the infrastructure } \\
\text { connecting RES facilities and } \\
\text { transmitting the energy they } \\
\text { produce. } \\
\text { - Contracts regulating relations } \\
\text { between parties are missing. } \\
\text { - Lack of penalties for non- } \\
\text { performance (e.g. if a network } \\
\text { operator fails to provide the } \\
\text { RES investor with Technical } \\
\text { Specifications, Stage } 3 \text { of } \\
\text { investment process). }\end{array}$ & & \\
\hline $\begin{array}{l}\text { Ineffectual } \\
\text { governance } \\
\text { structures and } \\
\text { mechanisms }\end{array}$ & $\begin{array}{l}\text { - The FSC struggles to establish } \\
\text { its credibility as a reliable } \\
\text { purchaser of clean energy, } \\
\text { lacking creditworthiness. } \\
\text { - Risk of unrecoverable debts and } \\
\text { inability to sell electricity } \\
\text { produced (for RES producers). } \\
\text { - Unclear procedure for inclusion } \\
\text { in the official list of approved } \\
\text { RES energy producers. } \\
\text { - Unclear timeframe for inclusion. } \\
\text { - No assessment criteria for } \\
\text { inclusion. }\end{array}$ & & \\
\hline $\begin{array}{l}\text { Inconsistent } \\
\text { development } \\
\text { of legal and } \\
\text { regulatory } \\
\text { framework }\end{array}$ & $\begin{array}{l}\text { - Uncertain legal and regulatory } \\
\text { environment. For example, often } \\
\text { laws are not supported by the } \\
\text { necessary regulatory provisions. } \\
\text { - Lack of supporting mechanisms } \\
\text { for certain stages of the } \\
\text { investment process. }\end{array}$ & & \\
\hline $\begin{array}{l}\text { Uncertainty } \\
\text { regarding the } \\
\text { resolution of } \\
\text { legal disputes }\end{array}$ & $\begin{array}{l}\text { - Foreign investors face } \\
\text { uncertainty regarding the } \\
\text { enforcement of arbitration } \\
\text { awards by Kazakhstani courts } \\
\text { and the enforceability of } \\
\text { judgements regarding contracts }\end{array}$ & & \\
\hline
\end{tabular}




\begin{tabular}{|l|l|l|l|}
\hline & $\begin{array}{l}\text { in which the governing law is } \\
\text { not the Kazakhstani one. } \\
\text { This presents significant risk for } \\
\text { investors. }\end{array}$ & & \\
\hline
\end{tabular}

Source: Compiled by the authors.

Assessment of the investment process through the lens of governance has identified a lack of rules and regulations guiding the work of bureaucrats and the existence of ineffective structures and procedures. A number of plausible explanations could be offered. First, there is the historically established, undeniable dominance of the oil and gas sector. The sector has been playing a key role in the nation's development to date and can be credited for its contribution to the rapid economic growth following the country's independence from the Soviet Union in 1991. It represents important vested interests and is supported by a powerful lobby. Consequently, it has significant influence on the strategic direction of the nation's energy and economic policies and on power holders and power brokers in government and regulatory bodies. This most likely accounts for the second plausible explanation, i.e. that there is disparity of views amongst key institutions (governmental and regulatory) as to the nation's energy future and the path to sustainable economic development despite the recent focus on green economy with a number of key policy statements and legislative actions. Third, there is the lack of understanding and appreciation of the long-term implications of the rapid depletion of fossil fuel reserves, global climate change and increased air pollution, all placing an increasingly stronger emphasis on the need for utilising clean energy sources as well as increasing energy efficiency (Brown at al., 2001; Hanson and Laitner, 2004). Our interviewees highlighted this lack of understanding in the Kazakhstani populace, which has the widely held belief that oil is an inexhaustible resource. This is potentially coupled with a lack of political will to engage the community in a dialogue about the nation's energy and economic future, and the importance of ensuring its long-term energy security and economic durability. This is likely to be true given Kazakhstan's weak civil society, weak or non-existent NGOs and weak citizens' engagement.

There are numerous implications resulting from all impediments as Table 2 outlines. Key amongst those are implications for the government and implications for the nation.

Given the number of problematic areas identified in relation to the current governance structures and processes, the government should focus on revising them, prioritising to tackle those with the potential for greater negative impact. Further, it should pay particular attention on devising incentive schemes for investors in the RES sector as well as network companies 
and the system operator to attract the much-needed private investment. Finally, in decisions on the design of governance structures and processes, prior to implementation, the government should incorporate the assessment of their implications to ensure they will lead to the desired outcome.

Limited progress in the development of the RES sector will lead to the continued dominance of the oil and gas sector with negative implications for the diversification of the economy related to the energy sector and the long-term energy security of the nation. It also means the continued reliance of the nation on oil and gas revenues and, consequently, the continued vulnerability of the budget to the volatility of oil price. Ultimately, this will inhibit Kazakhstan's attempts to move to a more sustainable economic development model and will jeopardise its economic durability.

Given Kazakhstan's long-term commitment to renewables in its policy, one may expect more effective governance in the future. Whilst a green energy policy has already been adopted, greater attention to the design of governance structures, procedures and incentives could make substantial difference to the sector.

\section{Footnotes:}

1. Legislative provisions include: A presidential decree in 1995 establishing the current electricity market structure; the Programme of Privatisation and Restructuring of the Power Sector (Government Resolution No. 663, 1996); the Law of the Republic of Kazakhstan (RK) about Energy Saving (December 25, 1997, No. 210-I); the Measures for Further Development of Market Relations in the Electric Power Industry of the RK (Government Resolution No. 190, 2004); the Law of the RK on Electric Power Industry (July 9, 2004, No. 588-II); the Law of the RK about Energy Saving and Increasing Energy Efficiency (January 13, 2012, No. 541-IV); the Law of the RK about Gas and Gas Supply (January 9, 2012, No 532-IV). Also, the Law of the RK about Architectural, Town Planning and Construction in the RK (2001, No. 242-II) and the Law of the RK about Subsoil Resources and Subsoil Use (June 24, 2010, No. 291-IV).

2. Regulatory provisions include Grid Code Rules and Rules for: the organisation and operation of the wholesale and retail electric energy markets of the RK and the centralised electric energy trading in the RK; the access and provision of services to the retail electric energy market; the operation of the balancing of the electric energy market; and rendering services by the system operator and the operation of the system and ancillary services market (KEGOC, 2017). 
3. Unified Power System: combination of power plants, transmission lines and substations.

\section{References}

Asian Development Bank. 2010. Sector assessment (summary): Energy. Based on the ADB sector knowledge and the Government of Kazakhstan. 2010. Government Programme on Accelerated Industrial-Innovative Development of the Republic of Kazakhstan, 2010-2014. Astana.

Bernard, R. B. and Ryan, G. W. 2010. Analyzing qualitative data. Thousand Oaks, CA: Sage.

Bhuiyan, S. H. and Amagoh, F., 2011. Public sector reform in Kazakhstan: Issues and perspectives. International Journal of Public Sector Management, 24: 227-249.

Brown, M.A., Levine, M.D., Short, W. and Koomey, J.G. 2001. Scenarios for a clean energy future. Energy Policy, 29: 1179-1196.

Decree of the President of the Republic of Kazakhstan 'On the Concept of transition of the Republic of Kazakhstan to 'green economy'. 2013. Dated May 30, 2013 No 577. Accessed October $\quad 2017 . \quad$ http://gbpp.org/wpcontent/uploads/2014/04/Green_Concept_En.pdf

Decree of the President of the Republic of Kazakhstan 'on the Concept of transition of the Republic of Kazakhstan to sustainable development'. 2006. Dated 2006, No 216. $\begin{array}{llll}\text { Accessed } & \text { October } & 22, & \end{array}$ http://climatepolicydatabase.org/index.php?title=The_Concept_of_Transition_of_the_ Republic_of_Kazakhstan_to_Sustainable_Development_for_the_Period_20072024,_Presidential_Decree_No_216_of_2006_Kazakhstan_2006

Energy Charter Secretariat. 2013. Investment climate and market review in the energy sector of Kazakhstan. Accessed January 5, 2017. www.energycharter.org/what-wedo/investment/investment-climate-and-market-structure/investment-in-kazakhstan$2013 /$.

Fukuyama, F. 2013. What is governance? Governance: An International Journal of Policy, Administration, and Institutions, 26(3): 347-368.

Guest, G., MacQueen, K. M. and Namey, E. 2012. Applied thematic analysis. Thousand Oaks, CA: Sage.

Hanson, D. and Laitner "Skip" J.A. 2004. An integrated analysis of policies that increase investments in advanced energy-efficient/low-carbon technologies. Energy Economics, 26: 739-755. 
Heckathorn, D. D. 1997. Respondent-driven sampling: A new approach to the study of hidden populations. Social Problems, 44(2): 174-199.

International Energy Agency (IEA). 2015. Easter Europe, Caucasus and Central Asia. Energy policies beyond IEA countries. Accessed January 5, 2017. www.iea.org/publications/freepublications/publication/IDR_EasternEuropeCaucasus_ 2015.pdf

International Finance Corporation (IFC). 2015. Investor guide, Development of renewable energy projects Kazakhstan. Accessed October 18, 2017. http://invest.gov.kz/uploads/files/2017/01/11/development-of-renewable-energyprojects-kazakhstan_en.pdf

Kazakhstan 2050. 2012. Strategy Kazakhstan-2050: new political course of the established state. Address by the President of the Republic of Kazakhstan, Leader of the Nation, N. Nazarbayev: December 14, 2012. Accessed January 5, 2017. https://strategy2050.kz/en/multilanguage/.

Kazakhstan Electricity Grid Operating Company (KEGOC) website. http://www.kegoc.kz/en/company/national-power-system. Accessed October 19, 2017. Klitgaard, R. 1988. Controlling Corruption. Berkeley, CA: University of California.

Land Code of the Republic of Kazakhstan. 2003. Code of the Republic of Kazakhstan of June 20, 2003 No. 442-II. Accessed January 14, 2017. http://adilet.zan.kz/eng/docs/K030000442_.

Law Gazette. 2013. Kazakhstan is a magnet for investors but its legal system is a work in progress. Authored by Maria Shahid. Accessed October 27, 2017. https://www.lawgazette.co.uk/practice/kazakhstan-is-a-magnet-for-investors-but-itslegal-system-is-a-work-in-progress/5038664.article

Law of the Republic of Kazakhstan 'on Amendments and Addenda to Some Legislative Acts of the Republic of Kazakhstan on the issues of transition of the Republic of Kazakhstan to a 'green economy'. 2016. Law of the Republic of Kazakhstan of July 1, 2016. $\begin{array}{llll}\text { Accessed } & \text { December } & 1017 .\end{array}$ https://www.dentons.com/en/insights/alerts/2016/october/11/law-on-the-transition-toa-green-economy-presented-inkazakhstan?utm_source=Mondaq\&utm_medium=syndication\&utm_campaign=ViewOriginal 
Law of the Republic of Kazakhstan 'on Support of the Use of Renewable Energy Sources'. 2009. Law of the Republic of Kazakhstan of July 4, 2009 No. 165-IV ZRK. Accessed January 5, 2017. http://cis-legislation.com/document.fwx?rgn=28433.

Meón, P.-G. and Sekkat, K. 2005. Does corruption grease or sand the wheels of growth? Public Choice, 122(1): 69-97.

REEEP (Renewable Energy and Energy Efficiency Partnership). 2014. Kazakhstan (2014). Accessed January 5, 2017. www.reeep.org/kazakhstan-2014.

Samruk-Green Energy website. www.samruk-green.kz/en/company/missiya-i-videnie/. Accessed January 11, 2017.

Saldana, J. 2009. The coding manual for qualitative researchers. Thousand Oaks, CA: Sage.

Thomas, R. D. 2006. A general inductive approach for analyzing qualitative evaluation data. American Journal of Evaluation, 27: 237-246. 